Website : http://dayamas.unmermadiun.ac.id/index.php/dayamas

\title{
PENTINGNYA PERLINDUNGAN MEREK DALAM DUNIA BISNIS
}

\author{
Anik Tri Haryani \\ Program Studi Ilmu Hukum, Universitas Merdeka Madiun, Alamat Jalan Serayu No 79, Kota Madiun, Kode Pos \\ 63133,E-mail : anik@unmer-madiun.ac.id
}

\begin{abstract}
Legal counseling aims to provide understanding and socialization to the public about the importance of brand protection in the business world. The brand is a sign that is attached to a item / service so that the goods / services are known by the community. Brands can also be used as promotional suggestions to consumers. But in reality there are still many small business actors who do not understand the importance of this brand. Therefore it is necessary to carry out counseling or socialization about the importance of the brand and how to register a brand. The method used is by approaching the community through counseling and socialization. Socialization was carried out in the village of Mojorayung, Wungu District, Madiun Regency, the village, there was a small and medium industrial. The Mojorayung village community is very enthusiastic with the counseling and they will be willing to provide brands to the goods they produce local government assistance.
\end{abstract}

Keywords--: protection, brand, business

\section{PENDAHULUAN}

Semakin pesatnya perkembangan ekonomi dan industri yang ditandai dengan beragamnya produk barang maupun jasa yang beredar di pasaran membuat pengusaha perlu menjaga kualitas produk yang dihasilkan. Berbagai cara dilakukan oleh pengusaha agar produknya tetap dipercaya oleh konsumen mengingat banyak juga peniruan produk suatu perusahaan yang telah terkenal. Seiring dengan hal tersebut, peranan merek sangat besar sekali dalam memberikan perlindungan terhadap barang dan jasa yang beredar. Merek sebagai salah satu wujud karya intelektual memiliki peranan penting bagi kelancaran dan peningkatan perdagangan barang atau jasa dalam kegiatan perdagangan dan investasi. Merek (dengan "brand image"-nya) dapat memenuhi kebutuhan konsumen akan tanda pengenal atau daya pembeda yang teramat penting dan merupakan jaminan kualitas produk atau jasa dalam suasana persaingan bebas. Untuk mengetahui perbedaan produk perusahaan satu dengan perusahaan lain, diperlukan adanya merek yang melekat pada produk perusahaan tersebut. Dengan adanya merek, diharapkan konsumen akan menjadi lebih mudah mengenali produk yang mampu memberikan kepuasan bagi yang menggunakan, sehingga tidak terjadi salah pilih dalam membeli produk.

\section{METODE PENELITIAN}

a. Metode penyuluhan dan sosialisasi

Penyuluhan dan sosialisasi tentang pentingnya merek dalam dunia bisnis dengan sasaran karang taruna sebagai pendamping UMKM, perangkat desa, dan masyarakat pelaku usaha.

b. Pendampingan dan monitoring

Pendampingan berupa pemberian konsultasi terkait pendaftaran merek dan pemasalahan yang dihadapi oleh masyarakat. 
Website : http://dayamas.unmermadiun.ac.id/index.php/dayamas

\section{HASIL DAN PEMBAHASAN}

Dalam dasawarsa terakhir ini, telah semakin nyata bahwa pembangunan harus bersandarkan pada industri yang menghasilkan nilai tambah yang tinggi. Pembangunan nasional yang mencakup seluruh aspek kehidupan bangsa diselenggarakan bersama oleh masyarakat dan pemerintah. Masyarakat menjadi pelaku utama pembangunan, dan pemerintah berkewajiban mengarahkan, membimbing, melindungi, serta menumbuhkan suasana dan iklim yang menunjang.

Kesepakatan Indonesia untuk merealisasikan gagasan mengenai ASEAN Free Trade Area (AFTA) serta keikutsertaan Indonesia sebagai anggota World Trade Organization (WTO) dan Asia Pacific Economic Cooperation (APEC), telah menunjukan keseriusan Pemerintah dalam mendukung sistem perekonomian yang bebas/terbuka, dan secara tidak langsung memacu perusahaan-perusahaan di Indonesia untuk lebih meningkatkan daya saingnya.

Semakin derasnya arus perdagangan bebas, yang menuntut makin tingginya kualitas produk yang dihasilkan terbukti semakin memacu pekembangan teknologi yang mendukung kebutuhan tersebut. Seiring dengan hal tersebut, pentingnya peranan hak kekayaan intelektual dalam mendukung perkembangan teknologi kiranya telah semakin disadari. Termasuk disektor Usaha Mikro Kecil dan Menengah (UMKM).

Peluang emas itu ada buat mereka yang cermat dan jeli. Tidak salah jika UMKM disebut-sebut sebagai primadona, karena usaha rakyat kecil yang bermodal kecil ini sarat dengan keunggulan. Antara lain pada sifatnya yang fleksibel, kemampuan menyerap tenaga kerja, serta kemampuan bertahan di kondisi ekonomi yang sulit. Pentingnya peran UMKM sebagai salah satu komponen penggerak roda perekonomian dan perdagangan kiranya terlihat pada tetap kokohnya sebagian besar usaha tersebut di saat masa krisis moneter. Tidaklah berlebihan kiranya jika dikatakan sektor UMKM memegang peranan penting dan menjadi tulang punggung perekonomian nasional. Oleh karena itu pemerintah perlu mamberikan fasilitas dan membantu para pengusaha mikro kecil menengah/UMKM agar mereka mampu bersaing di era persaingan bisnis yang cukup berat di tahun-tahun mendatang bahkan dalam menghadapi perdagangan bebas.

Mencermati UMKM yang ada, langkah strategis yang harus ditempuh oleh pengusaha yang bergerak dalam UMKM tersebut diletakkan pada kemampuan UMKM tersebut dalam membangun merek dipasaran. Untuk sampai pada pembentukan merek yang terkenal, maka perlu pengetahuan dan pemahaman tentang hukum merek. Sangat disayangkan sebagian besar pelaku UMKM belum mempunyai pengetahuan yang memadai tentang hak atas kekayaan Intelektual khususnya merek.

Saat ini berbisnis bagi mereka hanya kegiatan menjual dan mendapat keuntungan saja tanpa memikirkan investasi jangka panjang dengan membangun merek. Padahal seseorang yang memiliki jiwa entrepreneur, akan secara serius membentuk merek melalui inovasi kreatif. Kekuatan merek dapat memberikan nilai tambah yang tinggi pada suatu produk yang dihasilkan. Ketika suatu produk sudah memiliki brand (merek), nilai jualnya akan jauh lebih tinggi, dan tentu saja akan meningkatkan daya saingnya di pasaran.

Telah begitu banyak contoh yang dapat menjadi bukti bahwa usaha kecil dengan pengelolaan merek yang benar, akan menghasilkan sebuah kesuksesan. Merek mempunyai dua fungsi utama yaitu :

1. Merek merupakan tanda (sign) yang berfungsi untuk memperlihatkan kepada konsumen suatu ciri khusus dari barang atau jasa yang dilekatkan merek tersebut sehingga dapat dibedakan dengan barang atau jasa lain yang sejenis; 
Website : http://dayamas.unmermadiun.ac.id/index.php/dayamas

2. Dengan mengenal suatu merek dagang atu jasa, konsumen secara tidak langsung mengetahui kualitas barang atau jasa yang dilekatkan suatu merek;

3. Merek berfungsi untuk menunjukkan pada konsumennya, siapa produsen barang atau jasa bersangkutan.

Merek adalah suatu (gambar atau nama) yang dapat digunakan untuk mengidentifikasi suatu produk atau perusahaan di pasaran. Pengusaha biasanya berusaha mencegah orang lain menggunakan merek mereka karena dengan menggunakan merek, para pedagang memperoleh reputasi baik dan kepercayaan dari para konsumen serta dapat membangun hubungan antara reputasi tersebut dengan merek yang telah digunakan perusahaan secara regular.

Berdasar Pasal 1 butir 1 Undang-Undang Nomor 20 Tahun 2016 tentang Merek Dan Indikasi Geografis, dinyatakan bahwa Merek adalah tanda yang dapat ditampilkan secara grafis berupa gambar, logo, nama, kata, huruf, angka, susunan warna, dalam bentuk 2 (dua) dimensi dan/atau 3 (tiga) dimensi, suara, hologram, atau kombinasi dari 2 (dua) atau lebih unsur tersebut untuk membedakan barang dan/atau jasa yang diproduksi oleh orang atau badan hukum dalam kegiatan perdagangan barang dan/atau jasa.

Dari definisi tersebut paling tidak dapat disimpulkan beberapa fungsi merek sebagai berikut :

1. Merek merupakan tanda (sign) yang berfungsi untuk memperlihatkan kepada konsumen suatu ciri khusus dari barang atau jasa yang dilekatkan merek tersebut sehingga dapat dibedakan dengan barang atau jasa lain yang sejenis;

2. Dengan mengenal suatu merek dagang atu jasa, konsumen secara tidak langsung mengetahui kualitas barang atau jasa yang dilekatkan suatu merek;

3. Merek berfungsi untuk menunjukkan pada konsumennya, siapa produsen barang atau jasa bersangkutan.

Merek sangat penting dalam dunia periklanan dan pemasaran karena publik sering mengaitkan suatu imej, kualitas atau reputasi barang dan jasa dengan merek tertentu. Sebuah merek dapat menjadi kekayaan yang sangat berharga secara komersial. Merek suatu perusahaan seringkali lebih bernilai dibandingkan dengan aset perusahaan itu sendiri.

Selanjutnya merek juga berfungsi sebagai sarana promosi dan reklame bagi produsen atau pengusaha-pengusaha yang memperdagangkan barang-barang atau jasa yang bersangkutan. Di pasaran luar negeri merek-merek sering dipakai untuk menciptakan dan mempertahankan goodwill di mata konsumen. Merek tersebut adalah simbol dengan mana pedagang memperluas pasarannya di luar negeri dan juga mempertahankan pasaran tersebut. Goodwill atas merek adalah suatu yang tidak ternilai dalam memperluas pasaran.

Berdasarkan Undang-Undang No. 20 Tahun 2016 tentang Merek dan Indikasi Geografis merek terdiri dari 3 (Tiga) macam yaitu :

a) Merek Dagang :

Merek yang digunakan pada barang yang diperdagangkan oleh seseorang atau beberapa orang secara bersama-sama atau badan hukum untuk membedakan dengan barangbarang sejenis lainnya. (Pasal 1 angka (2) Undang-Undang Nomor 20 Tahun 2016 Tentang Merek dan Indikasi Geografis)

b) Merek Jasa :

Merek yang digunakan pada jasa yang diperdagangkan oleh seseorang atau beberapa orang secara bersama-sama atau badan hukum untuk membedakan dengan jasa-jasa sejenis lainnya. (Pasal 1 angka (3) Undang-Undang Nomor 20 Tahun 2016 Tentang Merek dan Indikasi Geografis)

c) Merek Kolektif :

Merek yang digunakan pada barang dan/atau jasa dengan karakteristik yang sama yang diperdagangkan oleh beberapa orang atau badan hukum secara bersama-sama untuk 
Website : http://dayamas.unmermadiun.ac.id/index.php/dayamas

membedakan dengan barang dan/atau jasa sejenis lainnya (Pasal 1 angka (4) UndangUndang Nomor 20 Tahun 2016 Tentang Merek dan Indikasi Geografis)

Suatu merek agar mendapatkan perlindungan hukum maka merek tersebut harus didaftarkan. Jika permohonan suatu merek telah memenuhi syarat-syarat sesuai dengan ketentuan dalam Undang-Undang Merek Nomor 20 tahun 2016, dan tidak terdapat sanggahan dari pihak manapun maka Direktorat Paten dan Hak Cipta akan menyelenggarakan pendaftaran dan mengumumkan secara resmi merek tersebut. Yang dapat mengajukan pendaftaran merek adalah :

1. $\quad$ Orang (person)

2. Badan Hukum (recht person)

3. Beberapa orang atau badan hukum (pemilikan bersama)

Fungsi Pendaftaran merek adalah :

1. Sebagai alat bukti bagi pemilik yang berhak atas merek yang didaftarkan.

2. Sebagai dasar penolakan terhadap merek yang sama keseluruhan atau sama pada pokoknya yang dimohonkan pendaftaran oleh orang lain untuk barang/jasa sejenis.

3. Sebagai dasar untuk mencegah orang lain memakai merek yang sama keseluruhan atau sama pada pokoknya dalam peredaran untuk barang/jasa sejenis.

Ketentuan yang mengatur mengenai syarat dan tata cara Permohonan Merek berdasarkan Undang-Undang No. 20 Tahun 2016 tentang Merek dan Indikasi Geografis diatur dalam :

1) Pasal 7 sampai dengan pasal 10 Undang-Undang Nomor 20 Tahun 2016

2) Pasal 1 hingga Pasal 6 Peraturan Pemerintah Republik Indonesia Nomor 23 Tahun 1993 tentang Tata Cara Permintaan Pendaftaran Merek.

\section{Prosedur pendaftaran merek yaitu :}

Tata cara pengajuan permohonan

Permohonan diajukan secara tertulis dalam bahasa Indonesia kepada Direktorat Jenderal dengan ketentuan:

a) Permohonan diajukan dengan menggunakan formulir yang bentuk dan isinya seperti contoh yang dilampirkan pada Peraturan Pemerintah Republik Indonesia No. 23 Tahun 1993 tentang Tata Cara Permintaan Pendaftaran Merek.

b) Pengisian formulir Permohonan tersebut wajib dilakukan dalam rangkap empat dengan mencantumkan:

(1) Tanggal, bulan dan tahun.

(2) Nama lengkap, kewarganegaraan, dan alamat pemohon.

i. Pemohon dapat terdiri dari satu orang atau beberapa orang secara bersama, atau badan hukum).

ii. Dalam hal permohonan diajukan oleh lebih dari satu pemohon yang secara bersama-sama berhak atas merek tersebut, semua nama pemohon dicantumkan dengan memilih salah satu alamat sebagai alamat mereka.

(3) Nama lengkap dan alamat kuasa apabila permohonan diajukan melalui kuasa.

(4) Tempat tinggal kuasa yang dipilih sebagai domisili hukumnya di Indonesia, apabila pemohon bertempat tinggal atau berkedudukan tetap diluar Negara Republik Indonesia.

(5) Warna-warni apabila merek yang dimohonkan pendaftarannya menggunakan unsur-unsur warna.

(6) Jenis barang dan/atau jasa yang termasuk dalam kelas yang dimohonkan pendaftarannya. Permohonan untuk dua kelas barang atau lebih dan/atau jasa dapat diajukan dalam satu permohonan. 
Website : http://dayamas.unmermadiun.ac.id/index.php/dayamas

(7) Nama Negara dan tanggal permintaan merek yang pertama kali dalam hal permohonan diajukan dengan hak prioritas.

c) Menandatangani Permohonan

(1) Permohonan ditandatangani Pemohon atau Kuasanya, dengan ketentuan dalam hal permohonan diajukan oleh lebih dari satu Pemohon yang secara bersama-sama berhak atas merek tersebut, permohonan tersebut ditandatangani oleh salah satu pemohon yang berhak atas merek tersebut dengan melampirkan persetujuan tertulis dari para pemohon yang mewakili.

(2) Dalam hal permohonan tersebut diajukan melalui Kuasa (Konsultan Hak Kekayaan Intelektual), Permohonan ditandatangani oleh Kuasa dengan ketentuan:

i. Surat Kuasa untuk itu ditandatangani oleh semua pihak yang berhak atas Merek tersebut

ii. Jika penerima Kuasa lebih dari satu orang, dan dalam surat kuasa tidak terdapat klausul "surat kuasa diberikan kepada kuasa-kuasa tersebut untuk bertindak, baik sendiri-sendiri maupun bersama-sama", menurut pendapat penulis, permohonan harus ditandatangani oleh semua penerima kuasa.

Setiap Permohonan wajib dilengkapi dengan:

1) Surat pernyataan pemilikan merek

Surat pernyataan itu harus ditandatangani oleh pemilik merek dan bermeterai cukup yang dengan jelas dan tegas menyebutkan bahwa:

- Merek yang dimohonkan pendaftaran adalah miliknya

- Merek yang dimohonkan pendaftaran tidak meniru merek orang lain baik untuk keseluruhan maupun pada pokoknya.

- Apabila tidak menggunakan bahasa Indonesia, surat pernyataan itu harus disertai terjemahannya dalam bahasa Indonesia.

2) Etiket Merek

Jumlah etika merek yang diperlukan adalah sebanyak dua puluh helai dengan ketentuan:

- Ukuran

Etiket itu berukuran maksimal $9 X 9 \mathrm{~cm}$ dan minimal $2 X 2 \mathrm{~cm}$

- Warna

Apabila etiket merek berwarna, harus disertai pula satu lembar etiket yang tidak berwarna (hitam putih)

- Terjemahan

Etiket merek yang yang menggunkan bahasa asing dan atau di dalamnya terdapat huruf selain huruf latin atau angka yang tidak lazim digunakan dalam bahasa indonesia wajib disertai terjemahannya dalam bahasa Indonesia, dalam huruf lain, dan dalam angka yang lazim digunakan dalam bahasa Indonesia.

3) Akta pendirian badan hukum

Apabila pemohon adalah badan hukum Indonesia, dilengkapi:

- Akta pendirian badan hukum yang termuat di dalam Tambahan Berita Negara

- Salinan yang sah akta pendirian badan hukum.

4) Surat Kuasa Khusus

Surat kuasa khusus diperlukan apabila permohonan diajukan melaui kuasa, dengan ketentuan Surat Kuasa Khusus itu selain harus menyebutkan untuk mengajukan Permohonan dengan menyebutkan Mereknya. Namun, Surat Kuasa Khusus ini mutlak diperlukan jika Permohonan diajukan oleh Pemohon yang bertempat tinggal atau berkedudukan tetap di luar wilayah Negara Republik Indonesia. Hal ini disebabkan, menurut ketentuan Pasal 10 ayat (1) Undang-undang No. 20 Tahun 2016 tentang Merek 
Website : http://dayamas.unmermadiun.ac.id/index.php/dayamas

dan Indikasi Geografis, permohonan yang diajukan oleh Pemohon yang disebutkan di atas wajib diajukan melalui kuasanya di Indonesia.

5) Pembayaran biaya

Permohonan harus disertai pembayaran biaya dalam rangka Permohonan, sesuai dengan jenis dan besar yang ditetapkan oleh Menteri Hukum dan Hak Asasi Manusia.

6) Bukti Penerimaan Permohonan

Apabila permohonan diajukan dengan menggunakan hak prioritas, permohonan harus disertai bukti penerimaan permohonan yang pertama kali yang menimbulkan hak prioritas, dengan disertai terjemahannya dalam bahasa Indonesia.

Selanjutnya dalam Undang-Undang Nomor 20 Tahun 2016 dapat dilihat dalam Pasal 6 Ayat (1) yang menyatakan : Permohonan harus ditolak oleh Direktorat Jenderal apabila Merek tersebut :

1) mempunyai persamaan pada pokoknya atau keseluruhannya dengan Merek milik pihak lain yang sudah terdaftar lebih dahulu untuk barang/jasa sejenis;

2) mempunyai persamaan pada pokoknya atau keseluruhannya dengan Merek yang sudah terkenal milik pihak lain untuk barang dan/atau jasa sejenis;

3) mempunyai persamaan pada pokoknya atau keseluruhannya dengan indikasi geografis yang sudah dikenal.

Selanjutnya, Pasal 6 ayat (3) menyatakan permohonan juga harus ditolak oleh Direktorat Jenderal apabila Merek tersebut:

1) merupakan atau menyerupai nama orang terkenal, foto, atau nama badan hukum yang dimiliki orang lain, kecuali atas persetujuan tertulis dari yang berhak;

2) merupakan tiruan atau menyerupai nama atau singkatan nama, bendera, lambang atau simbol atau emblem negara atau lembaga nasional maupun internasional, kecuali atas persetujuan tertulis dari pihak yang berwenang;

3) merupakan tiruan atau menyerupai tanda atau cap atau stempel resmi yang digunakan oleh negara atau lembaga Pemerintah, kecuali atas persetujuan tertulis pihak yang berwenang.

Merek dapat dianggap sebagai "roh" bagi suatu produk barang atau jasa. Merek sebagai tanda pengenal atau tanda pembeda dapat menggambarkan jaminan kepribadian (individuality) dan reputasi barang dan jasa hasil usahanya sewaktu diperdagangkan. Apabila dilihat dari sudut produsen, merek digunakan sebagai jaminan hasil produksinya, khususnya mengenai kualitas, di samping untuk promosi barang-barang dagangannya guna mencari dan meluaskan pasar. Selanjutnya, dari sisi konsumen, merek diperlukan untuk melakukan pilihan-pilihan barang yang akan dibeli. Apabila suatu produk tidak mempunyai merek maka tentu saja produk yang bersangkutan tidak akan dikenal oleh konsumen. Oleh karena itu, suatu produk (produk yang baik atau tidak) tentu memiliki merek. Bahkan tidak mustahil, merek yang telah dikenal luas oleh konsumen karena mutu dan harganya akan selalu diikuti, ditiru, "dibajak", bahkan mungkin dipalsukan oleh produsen lain yang melakukan persaingan curang. Perlindungan merek secara khusus diperlukan mengingat merek sebagai sarana identifikasi individual terhadap barang dan jasa merupakan pusat "jiwa" suatu bisnis, sangat bernilai dilihat dari berbagai aspek.

Dengan demikian, merek merupakan hal yang sangat penting dalam dunia bisnis. Merek sangat erat kaitannya dengan dunia perdagangan baik berupa perdagangan barang maupun jasa. 
Website : http://dayamas.unmermadiun.ac.id/index.php/dayamas

\section{KESIMPULAN}

Pelaksanaan pengabdian berjalan dengan lancar, masyarakat sangat antusias mendengarkan penjelasan dari narasumber dengan mengajukan berbagai macam pertanyaan yang belum mereka pahami tentang tata cara pendaftaran merek dan syarat-syarat pendaftaranya. Untuk keberlanjutannya pelaku usaha nantinya akan didampingi untuk membuat merek dan mendaftarkannya ke kantor Hak Cipta Paten dan Merek, paling tidak sebelum sertifikat mereknya disetujui mereka dapat mendaftarkan PIRT nya terlebih dahulu untuk menjamin kebersihan dan kehalalan produk yang mereka hasilkan.

\section{UCAPAN TERIMAKASIH}

Penulis ucapkan terimakasih kepada Universitas Merdeka Madiun yang telah memberikan sarana prasana kegiatan pengabdian, juga Pemerintah Desa Mojorayung yang telah memberikan bantuan perijinan untuk kegiatan ini, ucapan terimakasih disampaikan kepada Dinas Perdagangan dan Perindustrian yang telah mendampingi pelaku usaha selama ini, juga masyarakat Desa Mojorayung yang telah antusias menghadiri kegiatan penyuluhan dan sosialisasi. 
Website : http://dayamas.unmermadiun.ac.id/index.php/dayamas

\section{DAFTAR PUSTAKA}

\section{Literatur}

Djumhana, Djubaedillah, 2003, Hak Milik Intelektual Sejarah, Teori dan Prakteknya di Indonesia, Citra Aditya Bakti, Bandung

Ditjen Industri Kecil dan Menengah Departemen Perindustrian, 2003, Kebijakan Pemerintah Dalam Perlindungan Hak Atas Kekayaan Dan Liberalisasi, Jakarta

Hendra Djaja, 2009, Hukum Hak Kekayaan Intelektual, Surya Pena Gemilang, Malang

Insan Budi Maulana, 2007, Sukses Bisnis Melalui Merek, Paten, dan Hak Cipta, Bandung, Citra Aditya Bakti, Bandung

Saidin, 2009, Aspek-Aspek Hak Kekayaan Intelektual (Intelectual Properti Rights), Raja Grafindo Persada, Jakarta

Tim Lindsey, dkk, 2002, Hak Kekayaan Intelektual Suatu Pengantar, Alumni, Bandung

\section{Jurnal}

Wiratmo Dianggoro, Pembaharuan UU Merek dan Dampaknya bagi Dunia Bisnis, Artikel Jurnal Bisnis, Vol2, 1997

\section{Peraturan Perundang-Undangan}

Undang-Undang Nomor 20 tahun 2016 tentang Merek danIndikasi Geografis

Peraturan Pemerintah Nomor 23 Tahun 1993 tentang Tata Cara Permintaan Merek

\section{Internet}

http://www.ciputraentrepreneur.com 